\title{
Evaluation of Ascitic Fluid Neutrophil Gelatinase Associated Lipocalin in Patients with Spontaneous Bacterial Peritonitis
}

\author{
Hossam A. Biomy ${ }^{\text {a }}$, Naglaa El -Toukhy ${ }^{\text {a }}$, Alaa El Din I. Kandil ${ }^{\text {a }}$, Seham Gouda ${ }^{\text {b }}$, Zainab W. Galal ${ }^{\text {a }}$
}

${ }^{\mathrm{a}}$ Department of hepatology and gastroenterology, faculty of medicine, benha university, benha, Egypt. ${ }^{\mathrm{b}}$ Department of clinical pathology-Faculty of medicine-Benha University, Egypt.

Correspondence to: Zainab W. Galal, Department of hepatology and gastroenterology, faculty of medicine, benha university, benha, Egypt.

Email:

z.wageeh@yahoo.com

Received: 20 April 2021

Accepted: 11September 2021

\section{Abstract}

Background: A common bacterial infection of ascitic fluid in ascites due to liver cirrhosis is spontaneous bacterial peritonitis. Human neutrophil granules release a 24 KDA glycoprotein called neutrophil gelatinase associated lipocalin (NGAL). (NGAL) is a tissue injury and infection marker. Aim: The aim of this study was to determine the amount of NGAL in ascitic fluid in patients with liver cirrhosis and spontaneous bacterial peritonitis. Methodologies: A total of 85 patients with cirrhotic ascites were included in the study. 42 of them had SBP. The severity of liver cirrhosis was assessed using the Child-Pugh score, the Model for End Stage Liver Disease (MELD), and its update (uMELD) scores. Ascitic fluid samples were collected for leucocytic count differentiation, albumin, protein, glucose estimation, and the serum-ascetic albumin gradient. Both patients had their NGAL levels measured in their ascitic fluid. If the polymorph-nuclear leucocytic count in ascitic fluid was more than 250/ $\mathrm{mm}^{3}$, SBP was diagnosed. Results: The level of NGAL in ascitic fluid was significantly higher in patients with SBP. ROC analysis of ascitic NGAL as a marker for SBP diagnosis revealed: sensitivity of 97.62 percent, specificity of 97.67 percent, and area under curve (AUC) of 0.974 at a cut-off value of 100.8 (ng/dl). White blood cells, polymorph nuclear cells (PNCs) in ascitic fluid, Child Pugh score, MELD score and UMELD score all had a negative correlation with NGAL in non SBP group. Conclusion: In patients with spontaneous bacterial peritonitis, ascitic fluid NGAL may be a useful diagnostic marker.

Keywords: Neutrophil gelatinase associated lipocalin (NGAL), Ascites, Spontaneous bacterial peritonitis (SBP), Cirrhosis. 


\section{Introduction}

Cirrhosis is the most common cause of ascites, which is a pathologic accumulation of fluid in the peritoneal cavity [1]. Within 10 years of receiving a diagnosis of compensated liver cirrhosis, approximately $60 \%$ of patients develop ascites [2]. The 5year survival rate after the production of ascites is only $50 \%$ [3]. SBP is an infection of the previously sterile ascitic fluid that occurs without any clear intra-abdominal source of infection [4]. Outpatients with decompensated cirrhosis have a 3.5 percent incidence of SBP at one year, whereas hospitalised patients with cirrhosis and ascites have a 7 percent to 30 percent incidence of SBP at one year [5]. The mortality rate reported at 20-40\% among cirrhotic patients with ascites [6]. Enteric gram-negative bacteria cause over $60 \%$ of SBP episodes, with Escherichia coli (E coli) and Klebsiella pneumoniae being the most common germs isolated (K. pneumoniae). Gram-positive germs are found in $25 \%$ of SBP episodes, with streptococcal species isolated the most commonly [7]. SBP patients may have one or more of the following symptoms: Peritonitis symptoms and signs include abdominal pain, tenderness, vomiting, diarrhoea, and ileus.
Hyperthermia, hypothermia, chills, tachycardia, and/or tachypnea are also signs of systemic inflammation. Hepatic encephalopathy, shocking, renal dysfunction and bleeding in the intestines also may be one of presentation of SBP [8]. In the absence of a source of intra- abdominal infection, the most commonly used laboratory criterion for SBP diagnosis is an ascitic fluid neutrophil count $\geq 250$ cells/mm3 [9]. Human neutrophil granules release a 24 KDA glycoprotein called neutrophil gelatinase associated lipocalin (NGAL) [10]. NGAL is produced in the bone marrow during myelopoiesis and guided to the neutrophil granules, where it is processed. NGAL mRNA is also synthesized in non-hematopoietic tissues such as the epithelium of the colon, trachea, lung, and kidney [11]. Iron homeostasis, inflammation, microbial infection, organogenesis, neurodegeneration, and tumorigenesis have all been linked to NGAL [12]. SBP can be predicted by ascitic NGAL level [13].

The aim of this study was to determine the amount of NGAL in ascitic fluid in liver 
cirrhosis patients with and without spontaneous bacterial peritonitis.

\section{Patients and methods}

From June to December 2019, a crosssectional study was performed on 85 patients with cirrhotic ascites with and without spontaneous bacterial peritonitis who were admitted to Benha University Hospital's Department of Hepatology, Gastroenterology, and Infectious Diseases.

Approval by the committee of ethics of scientific research in Benha Faculty of Medicine in Benha University was obtained .All patients were verbally briefed about the study's procedures, with written consent obtained from all participants.

Criteria for inclusion: Cirrhosis of the liver and ascites in patients over the age of 18 .

Patients with ascites due to causes other than cirrhosis with portal hypertension, patients who have recently undergone abdominal surgery, organ transplant recipients, and patients who have reported colitis or enteritis were all excluded. In the previous 6 weeks, there was no history of gastrointestinal bleeding, antibiotics nor bacterial infections as (skin infections, chest infections, urinary tract infections, meningitis, dental infections gastroenteritis, biliary tract infections). Patients with kidney disease: Acute kidney injury in cirrhotic patients is described as an increase in serum creatinine of less than $0.3 \mathrm{mg} / \mathrm{dl} \quad(26.5$ Mmol/L) within 48 hours, or a percentage increase in serum creatinine of more than $50 \%$ within the previous seven days [14].Theses patients were excluded.

The following procedures were performed on all patients: a thorough medical history was taken. A full general and local examination was performed. The following investigations were done: complete blood picture, serum creatinine, liver profile, and serological tests for viral markers. Abdominal paracentesis for diagnostic purposes, Child Pugh score [15], MELD score [16], uMELD score [17] and ultrasonography of the abdomen were used in the study.

The patient was instructed on how to do paracentesis, which was performed under aseptic conditions with a small bore needle.

Each patient's ascitic fluid was aspirated, and samples were centrifuged at 2000rpm for 10 minutes, with the supernatant removed and stored at $-800^{\circ} \mathrm{C}$. Observed for: cytological review (complete leucocyte count with differentiation), total protein content, albumin, glucose and serum-ascites 
albumin gradient (SAAG) is the difference between serum albumin and ascitic fluid The amount of NGAL in ascitic fluid was determined using the ELISA technique. Lot \#: Bioassay Science Laboratory (E201905010). Reagents for human NGAL ELISA Kit Cat.No.E1719Hu were used. China is the source of this product.

\section{Statistical analysis}

STATA/SE version 11.2 for Windows was used to perform the statistical analysis (STATA Corporation, College Station, Texas).

For quantitative data, mean Standard Deviation (SD) and range were used, whereas for qualitative data, frequency and percentage were used. The Independent ttest ( $\mathrm{t}$ ) was used to detect differences in the mean between two parametric data and the Mann-Whitney (MW) test was used to detect differences between two nonparametric data when comparing the different sample groups. In the case of nonparametric data, the Kruskal Wallis test (KW) was used to detect differences between more than two groups. The Fisher Exact (FET) and the Chi-square test (x2) were used to detect differences in proportions as required. Correlation between ascitic fluid NGAL levels and estimated albumin.

parameters was evaluated using the Spearman Correlation coefficient (rho).

The diagnostic efficiency of ascitic fluid NGAL for SBP was evaluated using a Receiver Operating Characteristics (ROC) study. Positive Predictive Value (PPV), Negative Predictive Value (NPV), and Area under the Curve (AUC) were calculated to determine the best cut-off point and its corresponding sensitivity and specificity. Statistical significance was accepted at $\mathrm{P}$ value $<0.05(\mathrm{~S})$. A $\mathrm{P}$ value $<0.001$ was considered highly significant (HS) while a $\mathrm{P}$ value $>0.05$ was considered non-significant

\section{Results:}

Age was significantly higher in group I than group II. SBP was higher in males than females. HCV is the most common cause of liver cirrhosis, there was no statistically significant difference in viral markers between the two groups. Group I had significantly more abdominal pain, GIT bleeding, and fever than group II. Jaundice and hepatic encephalopathy were higher in group I than in group II. Group I had a significant lower haemoglobin levels than group II. Group I had significantly higher levels of white blood cells, aspartate 
aminotransferase (AST), total bilirubin, international normalised ratio (INR), and serum creatinine than group II. Group I had a significant higher child grade $(\mathrm{C})$, model end stage liver disease (MELD) and revised model end stage liver disease (uMELD) than group II, as shown in table 1.

Polymorphs nuclear leucocytes were found to be substantially higher in group I than in group II. Ascitic fluid protein and glucose levels were substantially lower in group I than in group II. Albumin in ascitic fluid and serum ascitic albumin gradient (SAAG), there was no statistically significant difference between the two classes. NGAL in ascitic fluid was significantly higher in group I than in group II, as shown in table 2 ROC analysis for ascitic NGAL as a marker for SBP diagnosis showed the following: at a cut-off value of 100.8 ( $\mathrm{ng} / \mathrm{dl})$, sensitivity is 97.62 percent, specificity is 97.67 percent, and the area under the curve (AUC) is 0.974, as shown in table 3 .

A significant negative correlation between NGAL, white blood cells and Child Pugh score. There was a negative correlation between NGAL, polymorph nuclear cells in ascitic fluid, MELD score and UMELD score, but it was not statistically important, as shown in table 4 . 
Benha medical journal, vol. 38, issue 3, 2021

Table 1. Baseline data of the studied groups.

\begin{tabular}{|c|c|c|c|}
\hline Parameters & $\begin{array}{l}\text { Group I with SBP } \\
\text { Number=42 }\end{array}$ & $\begin{array}{l}\text { Group II without SBP } \\
\text { Number }=43\end{array}$ & $P$ value \\
\hline Age $($ mean \pm SD) & $61 \pm 7.81 ;(40-78)$ & $56.44 \pm 6.73 ;(37-70)$ & $0.005(\mathrm{~S})$ \\
\hline \multicolumn{4}{|l|}{ Gender: } \\
\hline Male & $28(66.67 \%)$ & $28(65.12 \%)$ & 0.88 \\
\hline Female & $14(22.2 \%)$ & $15(34.88 \%)$ & \\
\hline HCV Ab & $38(90.48 \%)$ & $42(97.67 \%)$ & 0.20 \\
\hline HBS Ag & $3(7.14 \%)$ & $1(2.33 \%)$ & 0.36 \\
\hline Abdominal pain & $40(95.24 \%)$ & $5(11.36 \%)$ & $<0.001(\mathrm{HS})$ \\
\hline GIT bleeding & $28(66.6 \%)$ & $6(13.95 \%)$ & $<0.001(\mathrm{HS})$ \\
\hline Fever & $37(88.10 \%)$ & $7(16.28 \%)$ & $<0.001$ (HS) \\
\hline Jaundice & $27(64.29 \%)$ & $25(58.14 \%)$ & 0.56 \\
\hline $\begin{array}{l}\text { Hepatic } \\
\text { encephalopathy }\end{array}$ & $13(30.95 \%)$ & $10(23.26 \%)$ & 0.42 \\
\hline 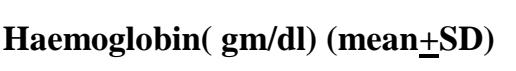 & $8.65 \pm 1.51$ & $9.2 \pm 1.42$ & $0.037(\mathrm{~S})$ \\
\hline $\begin{array}{l}\text { White blood cells (cells/Litre) } \\
(\text { mean } \pm \text { SD) }\end{array}$ & $7.93 \pm 5.4$ & $4.88 \pm 1.82$ & $0.001(\mathrm{~S})$ \\
\hline $\begin{array}{l}\operatorname{AST}(\mathrm{IU} / \mathrm{L}) \\
(\operatorname{mean} \pm \mathrm{SD})\end{array}$ & $79.57 \pm 55.8$ & $64.39 \pm 27.62$ & $0.02(\mathrm{~S})$ \\
\hline $\begin{array}{l}\text { Total bilirubin }(\mathrm{mg} / \mathrm{dl}) \\
(\operatorname{mean} \pm \mathrm{SD})\end{array}$ & $4.42 \pm 4.01$ & $2.96 \pm 1.68$ & $0.03(\mathrm{~S})$ \\
\hline $\begin{array}{l}\text { INR } \\
(\operatorname{mean} \pm \text { SD })\end{array}$ & $1.63 \pm 0.43$ & $1.4 \pm 0.37$ & $0.001(\mathrm{~S})$ \\
\hline $\begin{array}{l}\text { Creatinine }(\mathrm{mg} / \mathrm{dl}) \\
(\operatorname{mean} \pm \mathrm{SD})\end{array}$ & $1.81 \pm 1.12$ & $1.13 \pm 0.7$ & $0.002(\mathrm{~S})$ \\
\hline Child Pugh score: & & & \\
\hline Grade B & $12(28.57 \%)$ & $24(55.81 \%)$ & $0.01(\mathrm{~S})$ \\
\hline Grade C & $30(71.43 \%)$ & $19(44.19 \%)$ & \\
\hline MELD score & $21.09 \pm 7.89$ & $15.67 \pm 5.91$ & $0.001(\mathrm{~S})$ \\
\hline uMELD score & $3.68 \pm 0.45$ & $3.06 \pm 0.41$ & $<0.001(\mathrm{HS})$ \\
\hline
\end{tabular}


Mean \pm SD: mean \pm standard deviation.

(S) $=$ Significant, $\mathbf{P}$ value $(<\mathbf{0 . 0 5})$.

(HS)=Highly significant, $\mathbf{P}$ value $(<\mathbf{0 . 0 0 1})$.

HCV Ab: Hepatitis C virus antibody.

HBs Ag: Hepatitis B surface antigen.

GIT: Gastrointestinal bleeding.

MELD: Model End Stage Liver Disease.

uMELD: updated Model End Stage Liver Disease

Table2. Ascitic fluid analysis of the studied groups:

\begin{tabular}{|c|c|c|c|}
\hline Ascitic fluid analysis & $\begin{array}{l}\text { Group I with } \\
\text { SBP } \\
\mathrm{N}=42\end{array}$ & $\begin{array}{l}\text { Group II } \\
\text { without SBP } \\
\mathrm{N}=43\end{array}$ & $P$ value \\
\hline $\begin{array}{l}\text { Polymorphs nuclear leucocytes }\left(\operatorname{cells} / \mathbf{m m}^{3}\right) \\
(\operatorname{mean} \pm \mathbf{S D})\end{array}$ & $869.64 \pm 813.43$ & $126.16 \pm 78.68$ & $<0.001(\mathrm{HS})$ \\
\hline $\begin{array}{l}\operatorname{Albumin}(\mathrm{gm} / \mathrm{dl}) \\
(\text { mean} \pm \mathbf{S D})\end{array}$ & $1.07 \pm 0.26$ & $1.12 \pm 0.35$ & 0.48 \\
\hline $\begin{array}{l}\operatorname{Protein}(\mathrm{gm} / \mathrm{dl}) \\
(\operatorname{mean} \pm \mathbf{S D})\end{array}$ & $1.47 \pm 0.32$ & $1.73 \pm 0.21$ & $0.0001(\mathrm{HS})$ \\
\hline $\begin{array}{l}\operatorname{Glucose}(\mathrm{mg} / \mathrm{dl}) \\
(\operatorname{mean} \pm \mathbf{S D})\end{array}$ & $126.62 \pm 6.74$ & $134.95 \pm 8.84$ & $<0.001(\mathrm{HS})$ \\
\hline $\begin{array}{l}\text { Serum ascetic albumin gradient(SAAG) } \\
(\geq 1.1 \mathrm{mg} / \mathrm{dl}) \\
\left(\mathrm{mean}_{\mathbf{S}} \mathrm{SD}\right)\end{array}$ & $1.68 \pm 0.25$ & $1.69 \pm 0.28$ & 0.81 \\
\hline NGAL(ng/dl) & $171.55 \pm 89.13$ & $45.59 \pm 18.95$ & $<0.001(\mathrm{HS})$ \\
\hline
\end{tabular}


Benha medical journal, vol. 38, issue 3, 2021

Table 3: ROC analysis for ascitic NGAL as marker for diagnosis of SBP.

Cut-off level

Sensitivity

Specificity

Positive predictive value

Negative predictive value

Correctly classified

AUC $100.8(\mathrm{ng} / \mathrm{dl})$

$97.62 \%$

$97.67 \%$

$97.62 \%$

$97.67 \%$

$97.65 \%$

0.974

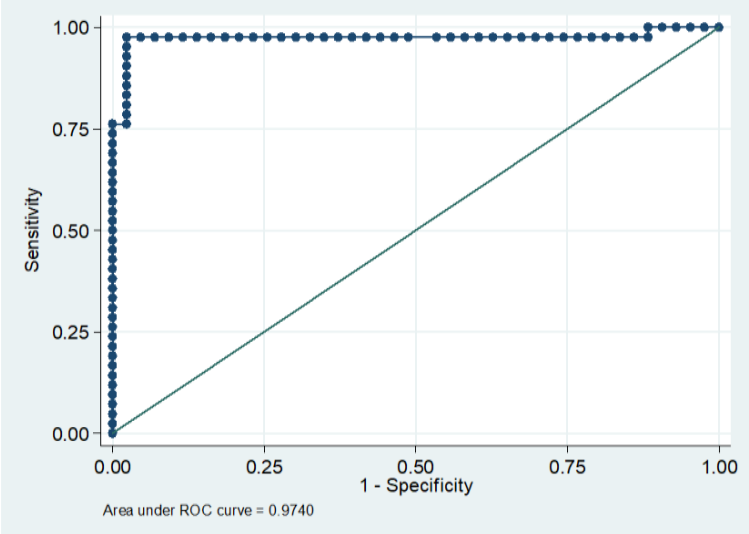

Fig1: ROC analysis for ascitic NGAL as marker for diagnosis of SBP.

Table 4: correlation between NGAL and some parameters in non SBP group.

\begin{tabular}{lll}
\hline Correlation of NGAL with & Correlation coefficient (rho) & P value \\
\hline White blood cells & -0.38 & $0.01(\mathrm{~S})$ \\
Polymorphs nuclear cells (PNCs) in ascitic fluid & 0.06 & 0.72 \\
Child Pugh score & -0.42 & $0.005(\mathrm{~S})$ \\
MELD score & -0.12 & 0.46 \\
uMELD & -0.06 & 0.68 \\
\hline
\end{tabular}

$(\mathrm{S})=$ significant, $\mathrm{P}$ value $(<0.05)$

\section{Discussion}

In patients with cirrhosis, bacterial infection

common form of infection (25 percent-31 is responsible for 30 percent to 50 percent of percent) [18]. Previous research has shown deaths. In patients with cirrhosis, that cirrhotic patients die at a rate of $20 \%$ to spontaneous bacterial peritonitis (SBP) is a $30 \%$ after an episode of spontaneous 
bacterial peritonitis (SBP) [19]. Patients with a PMN count of 250 cells $/ \mathrm{mm} 3$ in the ascitic fluid, regardless of bacterial isolation from the fluid, are diagnosed with SBP [20]. The $25-\mathrm{kDa}$ glycoprotein neutrophil gelatinase-associated lipocalin (NGAL), also known as lipocalin 2, was originally isolated from the individual granules of human PMN neutrophils, but it can also be synthesized to a lesser degree by tubular cells of the kidney, as well as the nucleus, uterus, prostate, salivary glands, lung, liver, trachea, stomach, and colon [21].

SBP patients had significantly higher ascitic NGAL levels $(171.55+89.13) \mathrm{ng} / \mathrm{dl}$ than non-SBP patients $(45.95+18.95) \mathrm{ng} / \mathrm{dl}$ in this sample. This was in accordance with Liu et al., 2020[22], who reported that ascitic NGAL levels were significantly higher in the SBP group than in the non-SBP group, with ascitic fluid NGAL present in 111 patients with SBP (83.9\%) compared to 48 patients without SBP (35.4\%), with a substantial statistical difference between the two groups. Infection and inflammation cause a rise in NGAL levels, which explains this.

Cullaro et al., 2017[13] found that ascitic NGAL levels were significantly higher in people with SBP [median (IQ) 221.3
(145.9-392.9) $\mathrm{ng} / \mathrm{dm}]$ than in people without SBP [139.2 (73.9-237.2) ng/ mL].

Lippi et al., 2013[21] found that the median concentration of NGAL in samples with 250 PMN/L was 3.4-fold higher than in samples with a PMN count below this threshold. This is explained by a rise in NGAL levels in infection (SBP), which is detected by PMN levels $\geq 250$ cells $/ \mathrm{mm}^{3}$ in ascitic fluid.

In the current research, the following ROC analysis was performed for ascitic NGAL as a marker for SBP diagnosis:

The cut-off value for ascitic NGAL as a marker for SBP diagnosis was 100.8 (ng/dl), the sensitivity was 97.62 percent, the specificity was 97.67 percent, and the area under the curve (AUC) was 0.974.

In the current study, the following parameters were correlated with NGAL in non- SBP group:

A significant negative correlation between NGAL, white blood cells and Child Pugh score. There was a negative correlation between NGAL, polymorph nuclear cells in ascitic fluid, MELD score and UMELD score, but not statistically significant. 


\section{Conclusion}

In conclusion, NGAL level was higher in ascitic fluid of SBP patients. Thus, it could be a diagnostic marker for SBP.

\section{References:}

1. Garcia-tsao, G. (2018). 15 - Ascites and Hyponatremia. In Zakim and Boyer's Hepatology (Seventh Ed). Elsevier Inc.: 220232.

2. Garbuzenko, D. V., \& Arefyev, N. O. (2019). Current approaches to the management of patients with cirrhotic ascites.World J. Gastroenterol., 25(28): 3738-3752.

3. Kogiso, T., Sagawa, T., Kodama, K., Taniai, M., \& Tokushige, K. (2018). Impact of continued administration of tolvaptan on cirrhotic patients with ascites. BMC Pharmacology and Toxicology, 19(1): 1-9.

4. Elsherif, A. A., Eldahshan, M. A., Hussein, M. S., \& Mohamed, A. M. (2016). Asymptomatic Spontaneous Bacterial Peritonitis in Adult Egyptian Patients with Decompensated Liver Cirrhosis: A Prospective Cohort Study. International Journal of Advanced Biomedicine, 1(1): 5-9.

5. Marciano, S., Díaz, J. M., Dirchwolf, M., \& Gadano, A. (2019). Spontaneous bacterial peritonitis in patients with cirrhosis: incidence, outcomes, and treatment strategies. Hepatic Medicine: Evidence and Research, 11: 13-22.

6. Metwally, K., Fouad, T., Assem, M., Abdelsameea, E., \& Yousery, M. (2018).
Predictors of Spontaneous Bacterial Peritonitis in Patients with Cirrhotic Ascites. Journal of Clinical and Translational Hepatology, 6(4): 1-5.

7. ALMEIDA, P. R. L. de, LEÃO, G. S., GONÇALVES, C. D. G., PICON, R. V., \& TOVO, C. V. (2018). Impact of Microbiological Changes on Spontaneous Bacterial Peritonitis in Three Different Periods Over 17 Years. Arquivos de Gastroenterologia, 55(1): 23-27.

8. Ajayi, A. O., Adegun, P. T., Ajayi, E. A., Raimi, H. T., \& Dada, S. A. (2013). Prevalence of spontaneous bacterial peritonitis in liver cirrhosis with ascites. Pan African Medical Journal, 15: 17.

9. José, T., Reginato, B., José, M., Oliveira, A., César, L., Lii, M., et al. (2011). Characteristics of ascitic fluid from patients with suspected spontaneous bacterial peritonitis in emergency units at a tertiary hospital Características do líquido ascítico de pacientes com suspeita de peritonite bacteriana espontânea nas unidades de eme. Sao Paulo Med. J. 2011; 129(5): 315-319.

10. Zhang, J., Gong, F., Li, L., Zhao, M., Wu, Z., \& Song, J. (2015). The diagnostic value of neutrophil gelatinase-associated lipocalin and hepcidin in bacteria translocation of liver cirrhosis. International Journal of Clinical and Experimental Medicine, 8(9): 16434-16444.

11. Martensson j and Bellomo R. (2014). The Rise and Fall of NGAL in Acute. Blood Purif, 37: 304-310.

12. Lu, F., Inoue, K., Kato, J., Minamishima, S., \& Morisaki, H. (2019). Functions and regulation of lipocalin-2 in gut-origin sepsis: a narrative review. Critical Care, 269(23): 1-8. 
13. Cullaro, G., Kim, G., Pereira, M. R., Brown, R. S., \& Verna, E. C. (2017). Ascites Neutrophil Gelatinase-Associated Lipocalin Identifies Spontaneous Bacterial Peritonitis and Predicts Mortality in Hospitalized Patients with Cirrhosis. Digestive Diseases and Sciences, 62(12): $3487-$ 3494.

14. Piano, S., Romano, A., Di, M., \& Paolo, P. (2017). Why and how to measure renal function in patients with liver disease. 37(October 2016): 116-122.

15. Pugh, R. N., Murray-Lyon, I. M., Dawson, J. L., Pietroni, M. C., \& Williams, R. (1973). Transection of the oesophagus for bleeding oesophageal varices. The British Journal of Surgery, 8(60): 646-649.

16. Kamath, P.S.; Wiesner, R.H.; Malinchoc, M.; Kremers, W.; Therneau, T.M.; Kosberg, C.L., et al (2001).A model to predict survival in patients with end-stage liver disease. Hepatology; 33:464-470.

17. Sharma, A.D.; Narain, N.; Händel, E.; Iken, M.; Singhal, N.; Cathomen, T., et al (2011).MicroRNA-221 regulates FAS-induced fulminant liver failure. Hepatology; 53:16511661.
18. Bunchorntavakul, C., Chamroonkul, N., \& Chavalitdhamrong, D. (2016). Bacterial infections in cirrhosis: A critical review and practical guidance. World Journal of Hepatology, 8(6): 307-321.

19. Hung, T. H., Tsai, C. C., Hsieh, Y. H., \& Tsai, C. C. (2015). The long-term mortality of spontaneous bacterial peritonitis in cirrhotic patients: A 3-year nationwide cohort study. Turkish Journal of Gastroenterology, 26(2): 159162.

20. Shizuma, T. (2016). Diagnostic Laboratory Markers for Spontaneous Bacterial Peritonitis. Annals of Clinical and Laboratory Research, 04(04): 1-5.

21. Lippi, G., Calef, A., Pipitone, S., Elia, G., Ngah, A., Aloe, R., et al. (2013).Assessment of neutrophil gelatinase-associated lipocalin and lactate dehydrogenase in peritoneal fluids for the screening of bacterial peritonitis. Clinical Chimica. Acta. 418: 59-62.

22. Liu, H., Zhu, P., Nie, C., Ye, Q., Gao, Y., Liu, H., et al. (2020). The value of ascitic neutrophil gelatinase-associated lipocalin in decompensated liver cirrhosis with spontaneous bacterial peritonitis. October 2019: 1-7.

To cite this article: Hossam A. Biomy, Naglaa El -Toukhy, Alaa El Din I. Kandil , Seham Gouda, Zainab W. Galal. Evaluation of Ascitic Fluid Neutrophil Gelatinase Associated Lipocalin in Patients with Spontaneous Bacterial Peritonitis. BMFJ 2021;38(3): 951-961. DOI: 10.21608/bmfj.2021.73302.1410 